\title{
Explaining Low Farm-Gate Prices in the Catalan Wine Sector
}

\author{
Montserrat Costa-Font ${ }^{1}$; Teresa Serra ${ }^{2}$; J. Maria Gil ${ }^{2}$ and Anna Gras ${ }^{3}$
}

\footnotetext{
${ }^{1}$ The Centre for Research in Agro-Food Economics and Development (CREDA-UPCIRTA), Edifici ESAB, Parc Mediterrani de la Tecnologia, Avda del Canal Olímpic s/n, 08860 Castelldefels, Spain Phone: +34-93-552-1213. Fax: +34-93-552-1121. Email:Montserrat.Costa-Font@upc.edu.

${ }^{2}$ The Centre for Research in Agro-Food Economics and Development (CREDA-UPCIRTA).

${ }^{3}$ The Polytechnic University of Catalonia (UPC), Barcelona, Spain.
} 


\title{
Explaining Low Farm-Gate Prices in the Catalan Wine Sector
}

\begin{abstract}
Purpose - The viticulture sector represents a conspicuous part of the Catalan agricultural and agro food sector. While wine production in Catalonia has been increasing markedly over the first half of the 2000s, prices that grape producers receive have steadily declined threatening their standard of living. This has raised social and political concerns and calls for a better understanding of its causes. Our analysis attempts to comprehend the sources of such price crisis.

Methodology - A Delphi survey was conducted during 2005 among a panel of 27 wine sector experts.

Findings - We find that experts agree in considering wine surplus and imperfect price transmission as the main causes determining low farm-gate prices in the Catalan wine sector.
\end{abstract}

Keywords: Delphi analysis, wine sector, price transmission.

Paper type: research paper. 


\section{Introduction}

As is the case with other European countries, the viticulture sector represents a conspicuous part of the Catalan agricultural and agro food sector. Wine making is an essential part of the economic and social identity of Catalonia and constitutes an important aspect of the region's landscape. While wine production has been increasing markedly over the first half of the 2000s, prices that grape producers receive have steadily declined threatening their standard of living. The decline in farm-gate prices contrasts with the stability of consumer prices. The economic situation of the wine sector has raised social and political concerns and calls for a better understanding of its causes.

When market mechanisms work smoothly, prices appear to be the main variable determining resource allocation, typically paying back marginal production costs. At the same time, prices are the primary mechanism by which different levels of the food marketing chain are related. The degree to which price changes are transmitted along this chain is usually a reflection of the level of competition within the market. Research on vertical price transmission within the food marketing chain has repeatedly reported imperfections such as asymmetries in this process (Goodwin and Holt, 1999; Serra and Goodwin, 2003; Peltzman, 2000). The literature also agrees on the fact that market conditions are largely important to understand how market imperfections work. Our analysis aims at characterizing the food marketing chain for wine products in Catalonia by quantifying the trade flows occurring within this chain. By doing so, we hope to provide useful insights concerning the process of price formation. Also, we attempt to determine the causes for the relevant increase in wine production within the last years and assess to what extent this increase constitutes a problem for the sector.

This study is divided in five main sections. The next section briefly describes the Catalan wine sector. Section three presents the methods employed. Section four reports the main results. The paper concludes with a summary of the results and the formulation of policy recommendations. 


\section{The Catalan wine grape production sector}

Worldwide, almost 8 million ha are assigned to grape production and as Table 1 exhibits, the total area has slightly increased during the last decade (by about $0.8 \%$ ). In contrast, the European grape area, which represents about $44 \%$ of worldwide grape area, has decreased by approximately 4\% in the 1999-2006 period. Following the same trend, the Spanish grape production area has declined by around $0.5 \%$. The Spanish grape sector is important as it represents about $34 \%$ of all European grape production area, with almost 1.2 million hectares. Previous studies suggest that the European and worldwide wine grape markets qualify as being saturated and mature (Calderon and Blanco, 2005; ICEX, 2006).

Table 1. Worldwide, European, Spanish and Catalan harvested grape area and wine production $(\mathrm{x} 1,000 \mathrm{hl})$.

\begin{tabular}{|c|c|c|c|c|c|c|c|c|c|}
\hline Year & & 1999 & 2000 & 2001 & 2002 & 2003 & 2004 & 2005 & 2006 \\
\hline \multirow{4}{*}{$\begin{array}{l}\text { Grape area } \\
(1,000 \text { ha })\end{array}$} & World & 7,864 & 7,885 & 7,893 & 7,955 & 7,953 & 7,919 & 7,930 & 7,924 \\
\hline & Europe & 3,553 & 3,588 & 3,547 & 3,515 & 3,490 & 3,468 & 3,439 & 3,410 \\
\hline & Spain & 1,180 & 1,237 & 1,235 & 1,202 & 1,207 & 1,200 & 1,180 & 1,174 \\
\hline & Catalonia & 59.4 & 65.4 & 64.3 & 64.9 & 65.4 & 67.8 & 62.9 & - \\
\hline \multirow{4}{*}{$\begin{array}{l}\text { Wine } \\
\text { production } \\
(1,000 \text { hl })\end{array}$} & World & 281,039 & 280,415 & 264,730 & 257,864 & 264,730 & 298,170 & 278,300 & 283,600 \\
\hline & Europe & 177,360 & 173,459 & 156,822 & 150,847 & 154,285 & 178,107 & 165,700 & 170,400 \\
\hline & Spain & 33,723 & 41,692 & 30,500 & 33,478 & 41,843 & 42,988 & 35,300 & 39,500 \\
\hline & Catalonia & 3,081 & 2,992 & 2,863 & 3,105 & 3,388 & 3,988 & 3,768 & 3,512 \\
\hline
\end{tabular}

Sources: World, Europe and Spanish data from International Organization of Vine and Wine (OIV); Catalan data for grape area from Spanish Ministry for Agriculture (MAPA) and Catalan Institute of Statistics (IDESCAT). Catalan data for wine production from Fondo Español de Garantía Agraria (FEGA) and MAPA.

Catalonia represents roughly 5\% $-63,000$ ha- of the Spanish grape production area (Table 1). Although the Catalan grape area is not especially relevant in magnitude, it is in quality. The Catalan viticulture sector is clearly specialized in quality wines, with around $95 \%$ of the vineyard area being devoted to produce "Quality Wine Produced in Specific Region" (Q.W.P.S.R.). Among Catalan quality vineyards it is possible to identify as much as eleven Protected Designations of Origin ${ }^{[1]}$ (PDOs). Among them Penedès is the most prominent in terms of vineyard area, production and sales. 
Annual Catalan wine production is around 3 million hectoliters, a 9\% of Spanish wine production (Table 1). PDOs represent around $90 \%$ of Catalan wine production. Despite a slight decline in output in 2001, especially for PDOs, a considerable increase takes place in the subsequent years. Catalan wine production patterns by PDO have changed over time. While PDO Penedès, Costers del Segre and Empordà have increased their relative importance, PDO Tarragona, Conca de Barberà and Terra Alta have lost relevance (Table 2). About $70 \%$ of the wine produced in Catalonia is devoted to white wine, a fact that can be explained by the relevance of Cava production (sparkling white wine) in Catalonia. Consistently with the evolution of total wine production, both white and red wine output increased during the first half of the 2000s.

Table 2. Catalan wine production by PDOs (hl)

\begin{tabular}{lrrrrrrr}
\hline & $\mathbf{1 9 9 8 / 1 9 9 9}$ & $\mathbf{1 9 9 9 / 2 0 0 0}$ & $\mathbf{2 0 0 0 / 2 0 0 1}$ & $\mathbf{2 0 0 1 / 2 0 0 2}$ & $\mathbf{2 0 0 2 / 2 0 0 3}$ & $\mathbf{2 0 0 3 / 2 0 4}$ & $\mathbf{2 0 0 4 / 2 0 0 5}$ \\
\hline Alella & 8,751 & 8,258 & 3,657 & 7,475 & 8,137 & $*$ & 7,018 \\
\hline Catalunya & $*$ & 197,541 & 371,800 & 338,353 & 299,128 & 299,088 & 335,895 \\
\hline Conca de Barberà & 51,306 & 27,526 & 78,807 & 52,782 & 35,154 & 30,605 & 22,018 \\
\hline Costers del Segre & 69,247 & 46,960 & 131,609 & 82,794 & 87,019 & 102,214 & 119,082 \\
\hline Empordà-Costa Brava & 36,091 & 58,740 & 47,611 & 62,000 & 60,087 & 57,019 & 59,959 \\
\hline Montsant & $*$ & $*$ & $*$ & 48,414 & 32,968 & 67,800 & 50,996 \\
\hline Penedès & 450,726 & 540,325 & 587,935 & 455,172 & 523,451 & 518,413 & 468,865 \\
\hline Pla de Bages & 10,991 & 12,320 & 12,000 & 10,950 & 11,800 & 12,700 & 10,900 \\
\hline Priorat & 6,413 & 3,443 & 4,732 & 4,875 & 1,857 & 16,766 & 4,117 \\
\hline Tarragona & 501,658 & 497,030 & 453,447 & 316,543 & 391,500 & 439,492 & 454,833 \\
\hline Terra Alta & 295,954 & 298,575 & 301,196 & 310,984 & 268,941 & 69,545 & 65,617 \\
\hline Source: unpul & & & & &
\end{tabular}

Source: unpublished data from Incavi (Catalan Institute of Wine and Vineyard)

Trends in consumption show a different pattern as Figure 1 illustrates. Although worldwide consumption has increased since the end of the 1990s (OIV), Spanish wine consumption has decreased and concentrated on PDO wines. Catalan wine consumption has experienced a much softer decrease and has also focused on PDO wines. Moreover, Spanish consumption is more centered on non Catalan PDOs such as Rioja and Ribera del Duero (AcNielsen, 2006a and b). Another remarkable issue arising from Figure 1 is that Catalan production exceeds consumption by far. 
"Take in Figure 1"

The fact that production surpasses consumption explains the positive Catalan wine trade balance. In particular, wine imports within the last years (1999-2005) have been around 38 million euros, whereas exports have represented about 340 million euros (Cámaras de Comercio, 2007). Currently, however, exports are growing more slowly than imports. This can be explained by changing consumer preferences and increased competition from other countries. Catalonia imports mainly from France, Portugal, Italy, Chile and Germany and exports to Germany, the USA, the UK and Sweden.

The excess production over consumption together with an increase in imports has had clear effects on prices. While consumer prices have not experienced noteworthy changes, farm-gate prices have significantly declined (Figure 2). This is consistent with Bukenya and Labys (2007) who confirmed a weak relationship between Spanish wine prices and wine inventories. The fact that a reduction in farm-gate prices does not translate into lower prices for wine, suggests the existence of imperfect price transmission within the food marketing chain (Goodwin and Holt, 1999; Serra and Goodwin, 2003; Peltzman, 2000). It may also suggest a scenario of inelastic demand and supply curves for wine (Fogarty, 2004). In such a scenario, the lower costs of grape production may not result in a reduction in wine prices. That is, the margin enjoyed by downstream channel members may automatically rise.

Paradoxically, low grape prices have not involved a reduction in grape production, which would have contributed to re-equilibrate the market. On the contrary, producers seem to have responded to low market prices by increasing output levels. This is consistent with producers aiming at stabilizing their income. Fogarty (2004) stated that countries with higher per capita levels of wine consumption and higher relative market shares have a more inelastic demand, being France, Spain, Portugal and Germany the most relevant examples. The decline in farm-gate prices coupled with inelastic demand and supply curves for wine has squeezed wine grape growers' margins and threatens their standard of living. 
Spanish wine grape growers' family farm income diminished from about 1,045 €/ha in 2003 to $685 € /$ ha in 2005 (MAPA, n.d.). Aggregate Spanish data are considered representative of the Catalan pattern, as the economic situation during the period studied was quite similar in all Spanish regions. Our analysis aims to improve the understanding of the reasons that have led to the present crisis situation, as well as the causes that justify an imperfect price transmission within the marketing chain. To do so, it is important to better comprehend the overall functioning of the food chain and identify the causes of production increases during the first half of the 2000s. A Delphi survey is used to assess these issues.

"Take in Figure 2"

\section{Data and methods}

As noted above, in a perfectly competitive market, the price of the final product should result from adding the marginal costs incurred by agents at each level of the marketing chain. However, market imperfections such as information asymmetry, market power, menu costs and search costs in local markets (Serra and Goodwin, 2003) may lead to imperfect transmission of prices along the chain. In agricultural markets this has been reported to be a serious concern. The recent evolution of wine grapes and wine prices suggest that imperfect price transmission may also be present within the Catalan wine marketing chain.

In order to gain a better understanding of price formation, it is necessary to have a deeper knowledge of the overall functioning of the marketing chain. Since there are no available statistical data on this issue, the Delphi method has been considered particularly relevant in providing the required information. The Delphi method has been successfully applied to examine different issues in a large variety of disciplines such as health (Milholland et at., 1973; Schoeman and Mahajan, 1977; and Oranga and Nordberg, 1993), policy (Critcher and Gladstone, 1998), and agriculture. In this latter discipline, the Delphi method has been used to examine Spanish olive oil exports (Mili and Rodríguez, 2001) ${ }^{[2]}$, the marketing of organic products (Padel and Midmore, 2005), the Finnish agricultural policy (Rikkonen et al., 2006) or the biotechnology and agrofood sector (Agrafiotis and Vagianou-Angelaki, 1999). 
The Delphi survey technique was first introduced in the early 1950's and was initially oriented to deal with technical topics such as reaching a consistent opinion for a complex issue (Turoff, 2002). Rather than an objective method to measure effects and causes of a specific phenomenon, it provides qualitative information that cannot be elicited through other methods. The objective of the Delphi analyses carried out is to reveal all the possible reasons that could explain current low farm-gate prices within the Catalan wine sector by achieving a consensus among experts (Turoff, 2002).

The survey was performed during 2005. The selection of the panel was acomplished following expert advice. The Polytechnic University of Catalonia has long been involved with studying the Catalan wine sector. Faculty and extension specialists were consulted and provided a list of agents. Experts on the wine sector from the Department of Agriculture of the Catalan Government also provided a directory of possible respondents. From these lists, we selected a final panel of 27 experts, all of them professionals belonging to different levels of the wine supply chain (wine grape growers, wineries, wholesalers and retailers). We also selected professionals from the Catalan agricultural public administration, regulatory councils and the University.

Three rounds were enough to obtain both the information needed as well as to increase the degree of consensus among experts. As for the first round, a preliminary questionnaire was sent and returned by mail. After this first reply, a second questionnaire was developed and completed also by mail. Finally, a third phase was carried out by means of expert face to face interviews, in order to contrast the results obtained in the second step. Respondents included about $63 \%$ of the panel and represented all supply chain stages, public authorities and the University.

The first-round survey was based on open questions aiming to identify the main problems related to the sector. Based on the reported replies the second Delphi questionnaire was built. This second-round consisted of a closed questionnaire where the respondents were asked to carry out quantitative and qualitative evaluations of different issues in order to better define and make suggestions to solve the main problems identified in the first round. Finally, second-round replies were ordered and structured using a third-round where respondents were presented with the obtained 
results and offered the chance to change their responses according to the information available. To determine a stopping criterion for the Delphi analysis, we measure stability of respondents over successive rounds of the Delphi following the method proposed by (Sheibe et al., 2002). This method consists of comparing the distributions of opinion between rounds. A maximum of a 15\% change level is chosen to represent a state of equilibrium. Since no significant change levels in third-round responses were observed, a fourth questionnaire appeared as unnecessary.

\section{Results and discussion}

a. First Round: Main wine sector problems expert assessment.

Since the wine supply chain is slightly complex and in order to gain a deeper understanding of the problems affecting the sector, in the first-round experts were inquired about the specific problems related to the different stages of wine production. In particular, they were questioned about the problems regarding wine grape growing, wine production, the structure of the sector, wine marketing within the domestic market, wine exports and, finally, other general problems. Results are presented in Table 3.

Respondents identify the lack of payment differentiation between grapes for PDO and non-PDO wines as being the main problem related to grape production, likely to be originated by over-production of grapes for PDO wines. Other deficiencies related to the national vineyard restructuring plan, a supply management policy, are identified. Experts consider inadequate restructuring schedules and grape varieties as the main shortcomings related to this plan. Finally, respondents believe that the Common Agricultural Policy (CAP), in its present form, is unable to preserve supply-demand equilibrium.

The utilization of concentrated and rectified grape must is one of the main problems of wine production, and it may allow middlemen in the marketing chain to pay reduced prices for wine grapes. Increases in wine imports follow in relevance amplifying the excess supply problem. As exhibited in Table 3, the main structural deficiencies of the wine sector are a lack of interprofessional agreements, a low degree of vertical integration, and an insufficient entrepreneurial dimension for international competition. 
Moreover, respondents believe that there exist too many intermediaries within the wine supply chain and that margins within the chain are excessive.

Wine marketing within national markets suffers from four main problems: restaurants' high margins and prices, hard competition from other Spanish and international wines, low and seasonal demand for Catalan wines both in Catalonia and in Spain and finally poor national marketing structures. Another shortcoming is the existence of too many Protected Designations of Origin (PDO) in Catalonia. The fact that Catalan wines are not sold under a common quality brand makes it more difficult the commercialization in Spain and in foreign countries relative to other Spanish PDOs such as Rioja comprising wider production areas. Barrère (2007) identifies that in Spain, Italy and France competition and segmentation is basically among PDO wines instead of between PDO and other wines. Therefore, the main objective of this certification, differentiation by quality, loses significance.

Finally, export limitations are also identified in Table 3. The low promotion of Catalan wines in foreign markets represents, according to experts, the main shortcoming affecting the sector which is related to the lack of collaborative agreements among different PDOs. Poor market structures, a slow down in export expansion and lack of knowledge of foreign markets have also been considered by experts as key problems for international wine marketing.

First-round survey results identified three main reasons that have induced a decline in farm prices while consumer prices remain constant: excess production, deficient marketing structures and imperfect price transmission along the marketing chain. In order to gain a deeper understanding of these problems a second-round Delphi questionnaire was designed. As for excess production, we directly inquire experts on the issue. With regards to price transmission and marketing structures we characterize the marketing chain so as to identify possible causes of why prices are not moving smoothly. 
Table 3. Expert assessment of the main problems of the wine sector (the qualifications go from 1 -not important to 10-very important)

\begin{tabular}{|c|c|}
\hline Grape production main problems & Average (Std.) \\
\hline Lack of differentiated payment for grapes for PDO wines & $7.4(2.7)$ \\
\hline Vineyard restructuring plans are not suitable concerning varieties & $6.3(2.3)$ \\
\hline Unsuitable moment for the application of vineyard restructuring plans & $5.9(2.7)$ \\
\hline Common Agricultural Policy (CAP) unable to preserve supply-demand equilibrium & $5.0(1.9)$ \\
\hline Wine production main problems & Average (Std.) \\
\hline Use of concentrated and rectified grape juice in wine production & $7.2(2.7)$ \\
\hline Use of sugar in wine production & $5.6(2.4)$ \\
\hline Import of wine from other production zones & $5.8(2.9)$ \\
\hline Structural main problems & Average (Std.) \\
\hline Low development of contractual regimes that contribute to stabilize the market & $6.9(2.5)$ \\
\hline Poor vertical integration & $6.8(2.7)$ \\
\hline Low entrepreneurial dimension for international competition & $6.4(2.7)$ \\
\hline High margins & $5.7(2.4)$ \\
\hline Too much intermediaries & $5.3(2.1)$ \\
\hline Main marketing problems - domestic market & Average (Std.) \\
\hline Restaurants: high margins and prices & $8.1(1.8)$ \\
\hline Price competition between Catalan wines and other wines from Spain and emerging countries & $8.0(1.6)$ \\
\hline Demand seasonality (Cava) & $7.7(1.9)$ \\
\hline Low demand in Spain & $6.9(2.8)$ \\
\hline Diluted image of Catalan wines within the Spanish market & $6.8(2.4)$ \\
\hline Poor marketing structures for domestic market & $6.1(2.3)$ \\
\hline Low demand in Catalonia & $5.7(2.9)$ \\
\hline Too many Protected Designations of Origin & $4.2(3.0)$ \\
\hline Main export Problems & Average (Std.) \\
\hline Low promotion of Catalan wine in foreign markets & $9.0(1.2)$ \\
\hline Lack of collaborative agreements among PDOs for foreign markets competition & $7.7(2.8)$ \\
\hline Poor market structures & $6.7(2.5)$ \\
\hline Slow down in export expansion & $6.6(2.5)$ \\
\hline Ignorance of foreign markets & $6.4(2.1)$ \\
\hline
\end{tabular}

Source: own source

\section{b. Second and third rounds}

\section{b.1. Characterizing the supply chain.}

The first objective of this second round is to provide a better understanding of the wine supply chain. To do so, we attempt to quantify trade flows for both red and white 
wines which follow different production processes and have different marketing chains. To that end, in the questionnaire a supply chain diagram with empty data was included in order to be completed (see Figures 3 and 4). Experts were asked to determine the percentage of output flowing to each different agent in each marketing level. According to their answers, wine supply chains can be characterized as follows.

Catalan young red (white) wine is made from about 90\% (88\%) Catalan wine grape and 10\% (12\%) concentrated grape juice. A 17\% (19\%) of this red (white) young wine will be diverted towards the production of non-PDO wines. Our panel of experts estimate that non-PDO red (white) wine produced in Catalonia is a blend of about $75 \%$ (79\%) Catalan young wine and 25\% (21\%) from other origins. On the other hand, about $83 \%(81 \%)$ of Catalan young red (white) wine is devoted to the production of PDO. From this, more than a $30 \%$ of the red wine is directed to an aging process and the remaining is consumed as bottled young wine with PDO. As for white wine, about a $30 \%$ goes to an aging process, $18 \%$ is consumed as bottled young wine with PDO and the remaining 59\% goes towards Cava (sparkling wine) production.

"Take in Figures 3 and 4"

On the basis of expert responses, it can be concluded that the Catalan red wine industry produces four key products: bulk wine without PDO (8\%), bottled wine without PDO (13\%), bottled young wine with PDO (54.5\%) and finally aged wine with PDO (24.5\%). On the other hand, the Catalan white wine yields five key products: bulk non-PDO wine (10\%), bottled PDO and non-PDO young wine (18\% and 9\% respectively), Cava (59\%) and finally aged wine qualified as PDO (4\%).

Moreover, it seems clear that there are four main wine market destinations both for red and white wines. As we can see in Table 4, exports represent around 30-40\% of total production in the region, domestic supermarket distribution represent about a $30 \%$, while around $25 \%$ of Catalan wine is consumed in restaurants and more than $10 \%$ is sold in wine stores. 
Table 4. Distribution of red and white wine by retail destination (\%).

\begin{tabular}{|c|c|c|c|c|c|}
\hline & & Exports & $\begin{array}{l}\text { Supermarket } \\
\text { distribution }\end{array}$ & $\begin{array}{l}\text { Restaurant } \\
\text { consumption }\end{array}$ & $\begin{array}{l}\text { Wine store } \\
\text { sales }\end{array}$ \\
\hline \multirow{5}{*}{$\begin{array}{l}\text { Red } \\
\text { wine }\end{array}$} & Total & 29.4 & 30.2 & 26.7 & 13.7 \\
\hline & In bulk (8\%) & 4.6 & - & 3.4 & - \\
\hline & Bottled and non-PDO (13\%) & 2.5 & 6.1 & 4.4 & - \\
\hline & Young and PDO (54.5\%) & 14.7 & 18 & 12.5 & 9.3 \\
\hline & Aged and PDO $(24.5 \%)$ & 7.6 & 6.1 & 6.4 & 4.4 \\
\hline \multirow{6}{*}{$\begin{array}{l}\text { White } \\
\text { wine }\end{array}$} & Total & 38.5 & 27.4 & 22.2 & 11.9 \\
\hline & In bulk $(10 \%)$ & 5.9 & - & 4.1 & - \\
\hline & Bottled and non-PDO (9\%) & 2.1 & 4.4 & 2.5 & - \\
\hline & Young and PDO (18\%) & 4.5 & 6 & 4.5 & 3 \\
\hline & Cava $(59 \%)$ & 25 & 16 & 10 & 8 \\
\hline & Aged and PDO (4\%) & 1 & 1 & 1.1 & 0.9 \\
\hline
\end{tabular}

Source: own source

From both red and white wine diagrams, it is worth mentioning the quantity of wine that is redirected from non-PDO to PDO wine. Approximately 23\% (25\%) of red (white) wine that initially enters the non-PDO wine marketing chain is readdressed towards the production of PDO wine. This contributes to our understanding of the observed price behavior: while a portion of grapes enter the distribution channel as nonPDO and thus receive lower prices than PDO grapes, they are finally used to produce PDO wines that will obtain higher retail prices.

It is also important to emphasize the role of cooperatives within the Catalan wine sector. Following expert quantifications, around half of Catalan grape production is controlled by cooperatives. While cooperatives play an undoubtedly relevant role, affiliation in the wine sector is lower relative to other food products and countries. For example, almost $70 \%$ of the milk produced within the EU-15 is marketed through cooperatives (Foro Agrario, 2000). In 2003, four of the ten main European cooperatives, in terms of revenue, specialized in dairy. In contrast, no wine cooperative existed within the raking (Confederación General de Cooperativas Agrarias de la UE-COGECA, 2005). The situation is not much different in Spain, where fruits, vegetables and olive oil cooperatives are abundant while wine cooperatives are scarce (COGECA, 2005). Spain had 625 wine cooperatives in 2003, not much compared to the 900 located in France, a direct competitor of Spain. Moreover, French cooperatives' turnover per year is almost twice that of Spanish ones (COGECA, 2005). 
Catalonia has around 77 wine cooperatives, which is $12 \%$ of all Spanish wine cooperatives (MAPA, 2004). This is compatible with Catalan wine production, representing around $10 \%$ of Spanish production. Low cooperative market shares coupled with an overall lack of marketing contracts within the wine sector involve reduced farmer negotiating power in price determination. Cooperatives can play a key role in marketing agricultural products by providing growers with a common database and by achieving economies of scale and thus lowering marketing and promotion costs. There is indeed a good experience with regards to cooperatives in the Catalan wine sector. The PDO Montsant, which was born in 2001, has been mainly promoted through cooperativism. Thanks to promotion strategies, the quality of Montsant wines is starting to be recognized outside Catalonia-almost a $70 \%$ of Montsant production is exported specially to Germany and the United States. Also in this sense, Garcia et al. (2002) explain that, for the Canary Island potato sector, vertical integration in agricultural cooperatives contributes to increase producer revenues by granting them participation to the added value during the commercialization process. From the expert's standpoint, cooperatives are more relevant within the white wine than within the red wine chain. This can explain the higher stability displayed by white wine farm-gate prices relative to red wine (see Figure 2).

Finally, the role of supermarkets on price determination, which have more power than the one exerted by small shops and restaurants, must also be considered. Excluding exports, supermarkets distribute almost half of Catalan wine. Supermarkets may be more reluctant to reprice their products than small specialty shops since the costs of doing so are higher. Low farm prices may not be immediately transferred to consumers. Consequently, supermarket power may also contribute to explain why retail prices have remained more or less constant while farm-gate prices have diminished.

\section{b.2 Qualitative evaluation of the Catalan wine surplus}

This section aims to elicit qualitative information on the prospects and situation of the Catalan wine sector production surplus. In order to better characterize the situation and predict its future evolution, experts were asked to forecast the overall economic situation of the sector within the next five years. Moreover, they were also asked to qualify the production surplus situation as temporary or permanent. Finally, the 
reasons that encourage excess supply in the Catalan wine sector were also identified (Table 5).

With respect to the economic forecast within the next five years, experts agree in considering the white wine (60\% of experts) and the Cava (more than $70 \%$ of the panel) sectors as quite stable sectors. However, some respondents point to moderate expansion or recession. In particular, around $20 \%(10 \%)$ of the panel believes that the Cava (white wine) sector will expand, while less than 10\% (30\%) predicts a recession. Agreement among experts is lower with regards to the economic forecast of the red wine sector. About $33 \%$ of the panel foresees a moderate expansion in the next future, $33 \%$ believes that the sector is stable, $20 \%$ predicts a moderate recession and finally a $13 \%$ foresees an important recession. ${ }^{[3]}$

A majority of panel members (around 60\%) define the current production surplus situation as permanent for white and red wines, more than $30 \%$ as structural and only $6 \%$ as temporary. There is, however, no agreement for the case of Cava: about $29 \%$ of the panel considers the situation as being temporary, $39 \%$ as structural with a possible solution and finally $32 \%$ as permanent. Furthermore, experts consider it easier to deal with white wine than red wine surplus, since the first can be redirected -in bulkto other European wine markets, reducing white wine stocks.

Finally, we elicited from experts the causes of Catalan wine surplus differentiating between red wine, white wine and cava. A list of possible causes were presented to the experts and they rateed each proposition from 0 - not at all important to 10 - very important. Table 5 presents the top ten surplus causes according to expert assessment. Interestingly, there was an agreement among expert panel members that the origins of production surplus are the lack of coordination and poor vertical integration in the overall Catalan wine sector. 
Table 5. Main expert assessed reasons for the surplus in the Catalan wine and cava sectors (From 0 - not at all important to 10 - very important).

\begin{tabular}{|c|c|c|c|c|c|}
\hline \multicolumn{2}{|l|}{ White wine } & \multicolumn{2}{|l|}{ Red wine } & \multicolumn{2}{|l|}{ Cava } \\
\hline Slow down in exports & $\begin{array}{r}5.9 \\
(2.9)\end{array}$ & $\begin{array}{l}\text { Scarce government control of cooperatives and } \\
\text { organizations }\end{array}$ & $\begin{array}{r}5.9 \\
(3.1)\end{array}$ & $\begin{array}{l}\text { Deficiencies in the control exerted by the } \\
\text { Regulatory Council }\end{array}$ & $\begin{array}{r}5.7 \\
(3.0) \\
\end{array}$ \\
\hline $\begin{array}{l}\text { Increase in production in order to keep farm rents in } \\
\text { a context of downward prices }\end{array}$ & $\begin{array}{r}5.9 \\
(2.8) \\
\end{array}$ & $\begin{array}{l}\text { Deficiencies in the control exerted by the } \\
\text { Regulatory Council }\end{array}$ & $\begin{array}{r}6.0 \\
(3.0) \\
\end{array}$ & $\begin{array}{l}\text { Increase in production in order to keep farm rents in } \\
\text { a context of downward prices }\end{array}$ & $\begin{array}{r}5.7 \\
(2.9) \\
\end{array}$ \\
\hline $\begin{array}{l}\text { Wine quality deterioration as a result of } \\
\text { overproduction }\end{array}$ & $\begin{array}{r}5.9 \\
(2.7) \\
\end{array}$ & Low demand in nearby markets & $\begin{array}{r}6.3 \\
(2.5)\end{array}$ & $\begin{array}{l}\text { CMO is not able to preserve supply-demand } \\
\text { equilibrium }\end{array}$ & $\begin{array}{r}5.7 \\
(2.6) \\
\end{array}$ \\
\hline $\begin{array}{l}\text { CMO is unable to preserve the supply-demand } \\
\text { equilibrium }\end{array}$ & $\begin{array}{r}6.4 \\
(2.5)\end{array}$ & $\begin{array}{l}\text { Wine quality deterioration as a result of } \\
\text { overproduction }\end{array}$ & $\begin{array}{r}6.4 \\
(2.7)\end{array}$ & Excess production goes to the detriment of quality & $\begin{aligned} 5.8 \\
(2.6)\end{aligned}$ \\
\hline Low demand in nearby markets & $\begin{array}{r}6.4 \\
(2.7)\end{array}$ & $\begin{array}{l}\text { CMO is not able to preserve supply-demand } \\
\text { equilibrium }\end{array}$ & $\begin{array}{r}6.4 \\
(3.4)\end{array}$ & Poor export marketing structures & $\begin{array}{r}6.3 \\
(3.2)\end{array}$ \\
\hline Low supports from public policy & $\begin{array}{r}6.7 \\
(3.3)\end{array}$ & Low supports from public policy & $\begin{array}{r}6.5 \\
(3.3)\end{array}$ & Low supports from public policy & $\begin{array}{r}6.4 \\
(2.7)\end{array}$ \\
\hline Poor export marketing structures & $\begin{array}{r}6.7 \\
(3.3) \\
\end{array}$ & Poor export marketing structures & $\begin{array}{r}6.5 \\
(2.4) \\
\end{array}$ & Lack of differentiated payment for quality grape & $\begin{array}{r}6.6 \\
(3.4) \\
\end{array}$ \\
\hline $\begin{array}{l}\text { Yields above permitted levels as a result of scarce } \\
\text { supply regulation }\end{array}$ & $\begin{array}{r}6.9 \\
(2.4)\end{array}$ & $\begin{array}{l}\text { Yields above permitted levels as a result of scarce } \\
\text { supply regulation }\end{array}$ & $\begin{array}{r}6.8 \\
(2.4)\end{array}$ & $\begin{array}{l}\text { Yields above permitted levels as a result of scarce } \\
\text { supply regulation }\end{array}$ & $\begin{array}{r}7.1 \\
(2.4)\end{array}$ \\
\hline Poor vertical integration & $\begin{array}{r}7.1 \\
(2.6)\end{array}$ & Poor vertical integration & $\begin{array}{r}7.1 \\
(2.6)\end{array}$ & Poor vertical integration & $\begin{array}{r}7.3 \\
(2.6)\end{array}$ \\
\hline Wine sector lack of coordination & $\begin{array}{r}7.7 \\
(2.6)\end{array}$ & Wine sector lack of coordination & $\begin{array}{r}7.7 \\
(2.6)\end{array}$ & Wine sector lack of coordination & $\begin{array}{r}7.8 \\
(2.6)\end{array}$ \\
\hline
\end{tabular}

Source: own source

Note: Values are expressed at the data means and standard deviations are in parenthesis 
Excessive production due to soft supply regulation and the inability of the Common Market Organization (CMO) for wine to preserve market equilibrium are also considered as possible reasons for wine surplus. Other regulation-related causes are identified, such as low support from the government towards the wine sector and low public control of cooperatives and cellar management to ensure good oenological practices. Furthermore, export market limitations have also been highlighted by experts as a reason for wine surplus. Indeed, survey respondents reveal that the Catalan export marketing strategy is not effective enough and encounters difficulties when competing against other low-price quality wines such as Australian, Argentinean and Chilean wines. Finally, the tendency to increase production in response to price declines so as to maintain farm income has also been considered as an important factor.

\section{Discussion and conclusions}

The Catalan wine sector is currently immersed in a crisis situation characterized by excess production and low farm-gate prices. The tendency of farm-gate prices to decline contrasts with the stability displayed by consumer prices. This study has attempted to determine the underlying causes of this situation. Catalonia is one of the main European PDO wine producing areas and the evidence presented in this analysis can provide some insights relevant for further empirical and theoretical analysis. It is however important to note that since this paper is based on qualitative data, all the findings should be treated as indicative not conclusive. Further validation through large-scale surveys would be interesting for future research. Closely following the evolution of the wine sector during the next few years would help determine the future relevancy of our results and policy recommendations.

First-round results from the Delphi study agree in considering excess production, deficient marketing structures and imperfect price transmission as the main causes determining low farm-gate prices in the Catalan wine sector. The second and third rounds of the analysis were carried out to provide a deeper understanding of both the motivating causes of excess production and the overall functioning of the marketing chain. 
Results show that although marketing chains for white and red wines are different, they present similar characteristics that suggest the existence of imperfect vertical price transmission. Specifically, while a portion of grapes are purchased and enter the distribution channel as wine grapes for non-PDO wines, they are later redirected towards the production of PDO wine. Also, the role of cooperatives, though relevant in absolute terms is smaller relative to other food sectors. These facts, coupled with the significant role played by supermarkets that usually exert strong market power, contribute to help understand why farm-gate prices decline while consumer prices remain stable.

Other causes are identified by experts in the first-round qualitative assessment as causing imperfect price transmission along the marketing chain. These causes are the scarce development of contractual regimes among agents, poor vertical integration and abnormal margins among certain distributors. Moreover, experts reveal that, even though the public administration is aware of these problems, efforts put forward to help the sector to prevent them are very limited.

Qualitative results from the Delphi study allow us to point to the main causes responsible for the current production surplus affecting the sector: the lack of coordination and poor market integration in the overall Catalan wine sector, deficiencies in the public regulation of the sector, a slow down in exports and domestic sales and finally an increase in production so as to maintain farm income levels in a context of price declines. Interestingly, experts identify this situation as being a structural phenomenon for white and red wine, whilst for Cava it seems to be only a temporary condition. Moreover, experts are more concerned about red than white wine due to the bulk-export possibility for the latter.

Based on the results from the Delphi survey, several policy and managerial implications emerge. It seems interesting to implement polices that help to improve integration for all stages of wine production, from grape growing to wine selling. This implies reducing the number of intermediaries and promoting a high level of professionalization within the sector. Vertical integration may help to reduce margin concentration at certain levels of the marketing chain. It would also be useful to standardize the parameters that are taken into account to define the quality of grapes by 
wine makers, and to promote the economic compensation for quality production. This latter measure could induce a reduction in overproduction.

The slow down in demand both at the national and international levels seems to be a result of poor knowledge of Catalan wines which limits the chances to introduce them in foreign markets. Some experts argue in favor of promoting an agreement among PDOs regarding promotional strategies along with supports from public authorities. This would imply less competition among PDOs, more consumer information about Catalan wines and thus a likely increase in domestic consumption and/or exports.

Moreover, the impending EU wine market reform can help reducing overproduction since it will ban the use of sugar for enriching wine. This will have a positive impact on quality payment differentiations and is likely to reduce overproduction. Also, better labelling rules and a budget for promoting information campaigns for wines with Geographical Indications is likely to positively affect grape for PDO wine payments. However, the elimination of market management measures, such as crisis distillation can have a negative impact on overproduction.

The first limitation of this study is associated with the Delphi method. Implementing the Delphi questionnaire is time consuming and this implies that not many rounds can be developed. Another important limitation is the lack of transparency within the Catalan wine sector, making it complex to extract information from the agents involved and limits the availability of experts to participate in the study. Indeed, a bigger expert panel would help in making a more accurate diagnosis of the situation of the sector. Finally, some of the data required, such as farm-level economic data, are not easily available making it even more difficult to gain a deeper understanding of the situation of the sector. 


\section{References}

ACNielsen, (2006a), "Resultados del estudio sobre la imagen y posicionamiento de la DO calificada rioja en el mercado nacional e internacional", Available at: http://www.riojawine.com/es/actualidad/noticias/noticias/media2006/graficosnielsen200 6.pdf (accessed May 2007).

ACNielsen, (2006b), "El Mercat del Vi, informe desembre - gener 2006", available at: http://www.gencat.net/darp/c/incavi/doc/inform.pdf (accessed May 2007).

Agrafiotis, D. and Vagianou-Angelaki, D. (1999), "Biotechnology and Agro-Food sector: Assessment of Environmental Impacts and the Questions of Sustainability", Paper presented at the $1^{\text {st }}$ POSTI workshop, the Annual ESST Scientific Conference, Lausanne, Switzerland, 29-30 May.

Barrère, C. (2007), "The genesis, evolution and crisis of an institution: the Protected Designation of Origin in wine markets", Journal of Institutional Economics, Vol.3 No. 2, pp 165-181.

Bukenya, J. and Labys, W.C. (2007), "Do fluctuations in wine stocks affect wine prices?", American association of wine economics working paper, No.8, available at: http://www.wine-economics.org/workingpapers/AAWE_WP08.pdf (accesed November 2007).

Calderon, M. and Blanco, L. (2005), “Análisis multivariado aplicado al mercado mundial de vinos", Paper presented at the Annual meeting of the Asociación Argentina de Economía Política, 16-18 November, La Plata, Argentina, available at: http://www.aaep.org.ar/espa/anales/works05/calderon blanco.pdf (accessed May 2007).

Cámaras de Comercio, Database, available at: http://aduanas.camaras.org/(accessed May 2007).

Catalan Department of Agriculture (DAR) (n.d.), "Preus percebuts pel pagès, Catalunya 20002007. Base 2000", available at http://www.gencat.net/darp/c/dades/preupp/preupp04.htm (accesed November 2007).

Confederación General de Cooperativas Agrarias de la UE (COGECA) (2005), "Las Cooperativas Agrarias en Europa. Cuestiones Fundamentales i Tendencias", available at: http://www.ccae.es/ficheros/doc/01470.pdf (accessed May 2007).

Confederación de Cooperativas Agrarias En España, "Cooperativismo en cifras", available at: http://www.ccae.es/ (accessed May 2007).

Critcher, C. and Gladstone, B. (1998), "Utilizing the Delphi Technique in Policy Discussion: a Case Study of a Privatized Utility in Britain", Public Administration, Vol.76, pp. 43149.

Fogarty, J. (2004), "The Own-Price Elasticity of Alchohol: A Meta-analysis", Working paper, The University of Western Australia Business School. available at: http://www.biz.uwa.edu.au/home/research/discussionworking_papers/economics/2004?f $=150991 \% 20$ - $($ accessed October 2007) 
Fondo espanyol de Garantía Agraria (FEGA) (n.d), "Recapitulación de las declaraciones de existencias de vinos de mesa y V.C.P.R.D.", available at: http://www.fega.es/fgpweb/fgp inicio (accessed November 2007)

FORO AGRARIO (2000), La reforma de la PAC de la Agenda 2000 y la Agricultura Española, Mundi-Prensa, Madrid.

Garcia, A.M., Oreja, J.R. and Gonzalez, E. (2002), "Las relaciones verticales y el poder de negociación de los agricultores integrados en forma de cooperativa frente a los individuales", CIRIEC-España, Revista de Economía Pública, Social y Cooperativa, Vol.41, pp. 111-137.

Goodwin, B. K. and Holt, M. T. (1999), "Price Transmission and Asymmetric Adjustment in the U.S. Beef Sector", American Journal of Agricultural Economics, Vol. 81 No.3, pp. 630-637.

ICEX, Oficina Económica y Comercial del Consulado General de España en Dusseldorf (2006), "Estudio de mercado: El mercado del vino en Alemania", available at: http://cendoc.esan.edu.pe/exportar/textocompleto/vino.pdf (accessed May 2007).

Milholland, A.V., Wheeler, S.G. and Heeiec, J.J. (1973), "Medical Assessment by a Delphi Group Opinion Technique", New England Journal of Medicine, Vol. 288, pp. 1272-5.

Mili, S. and Rodríguez, M. (2001), "Exploring Future Developments in International Olive Oil Trade and Marketing: A Spanish Perspective", Agribusiness, Vol. 17 No.3, pp. 397415.

Ministerio de Agricultura Pesca i Alimentación (MAPAa), (n.d.), "Anuarios de estadística agroalimentaria, 2003; 2004 and 2006", available at: http://www.mapa.es/ (accessed May 2007).

Ministerio de Agricultura Pesca y Alimentación (MAPAb), (2000;2001;2002;2003;2004;2005;2006), La alimentación en España, Madrid.

Ministerio de Agricultura Pesca y Alimentación (MAPA) (2004), "Estudio sobre la comercialización agroalimentaria en el sector cooperativo español", available at: http://www.mapa.es/ (accessed May 2007).

International organization of vine and wine (OIV) (1999; 2000;2001; 2002; 2003 and 2004), "Situation and statistics of the world vitiviniculture sector", available at: http://www.oiv.int/ (accessed May 2007).

Institut d'estadística de Catalunya (Idescat) (2003 and 2005), "Enquesta sobre l'estructura de les explotacions agrícoles", available at: www.idescat.net (accessed May 2007).

Oranga, H.M. and Nordberg, E. (1993), "The Delphi Panel method for Generating Health Information", Health Policy and Planning, Vol. 8 No. 4, pp. 405-12.

Padel, S. and Midmore, P. (2005), "The development of the European Market for organic products: insights from a Delphi study", British Food Journal, Vol. 107 No.8, pp. 626617. 
Peltzman, S. (2000), "Prices Rise Faster Than They Fall", Journal of Political Economy, Vol. 108 No. 3, pp. 466-502.

Rikkonen, P., Aakkula, J. and Kaivo-Oja, J. (2006), "How can Future Long Term Changes in Finnish Agriculture and Agricultural Policy de Faced? Defining Strategic Agendas on the Basis of a Delphi Study", European Planning Studies, Vol. 14 No. 2, pp. 147-67.

Salazar, M. and Sayadi, S. (2006), "El Delphi como Método de Análisis de la Coherencia de la PAC desde la prespectiva social", Paper presented at the IX Encuentro de Economía Aplicada, 8-9-10 June, Jaen, Spain.

Sackman, H. (1975), Delphi critique, Lexington Books, Lexington, MA.

Sheibe, M. Skutsch, M. and Schofer, J. (2002), "Experiments in Delphi Methodology", in Linstone, H.A. and Turoff, M. (2002), The Delphi Method: Techniques and Applications, available at: http://is.njit.edu/pubs/delphibook/ (accessed November 2007).

Soliño, M. (2003), "Programas Forestales en las Comunidades de Montes Vecinales en Mano Común de la Red Natura 2000: un Análisis Delphi”, Revista Gallega de Economía, Vol. 12 No. 1, pp. 225-246.

Serra, T. and Goodwin, B.W. (2003), "Price Transmission and asymmetric adjustment in the Spanish dairy sector", Applied Economics, Vol. 35, pp. 1889-1899.

Shoeman, M.E.F. and Mahajan, V. (1977), "Using the Delphi Method to Asses Community Health Needs", Technology Forecasting and Social Changes, Vol. 10, pp. 203-10.

Stewart, T. R. (1987), "The Delphi technique and judgmental forecasting”, Climatic Change, Vol.11, pp. 97-113.

Turoff, M. (2002), "The Policy Delphi”, in Linstone, H.A. and Turoff, M. (2002), The Delphi Method: Techniques and Applications, available at: http://is.njit.edu/pubs/delphibook/ (accessed May 2007). 


\section{Figures}

Figure 1. Spanish wine consumption and Catalan wine consumption and production.

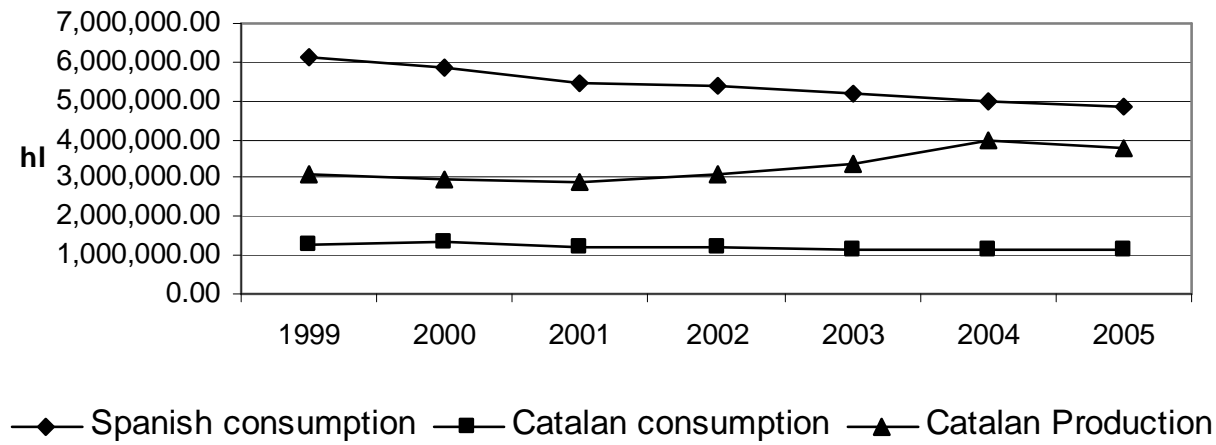

Source: Source: Ministerio de Agricultura Pesca y Alimentación (MAPA a,b) and Fondo Espanyol de de Garantía Agraria (FEGA) (n.d).

Figure 2. Evolution of Catalan farm-gate wine prices and Catalan and Spanish retail wine prices (In constant currency units)

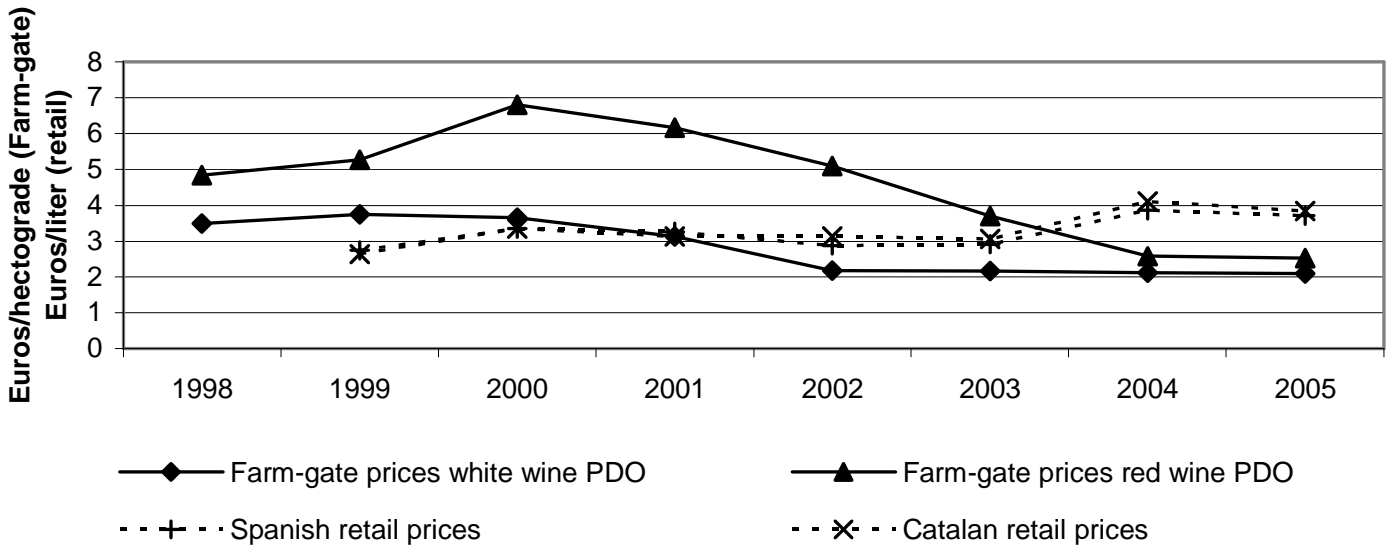

Source: Catalan Department of Agriculture (DAR, n.d.) and MAPAb 
Figure 3. Catalan red wine supply chain diagram.

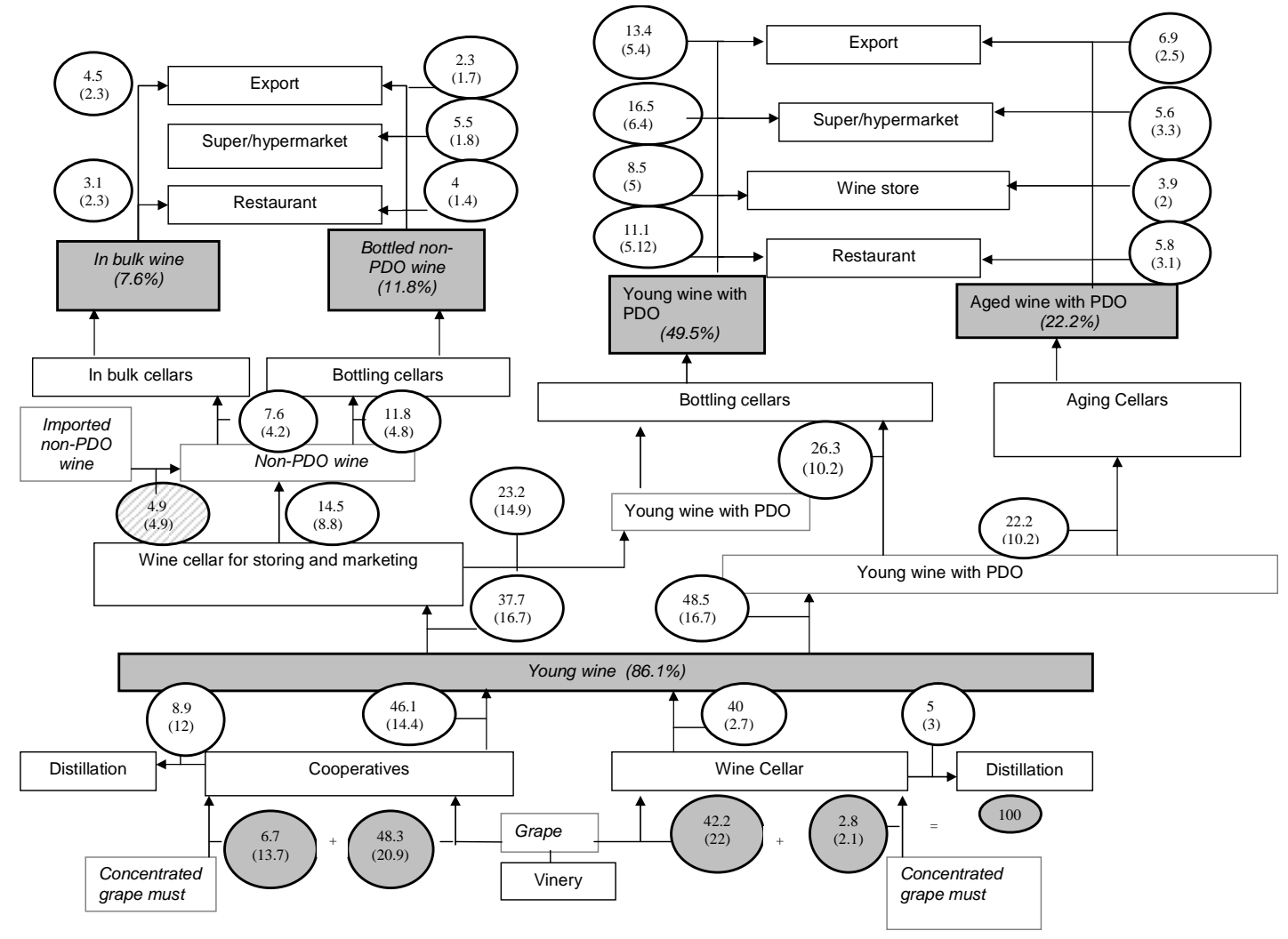

Source: own source

Note: Values are expressed in $\%$ and are at the data means. Standard deviations are in parenthesis 
Figure 4. Catalan white wine supply chain diagram.

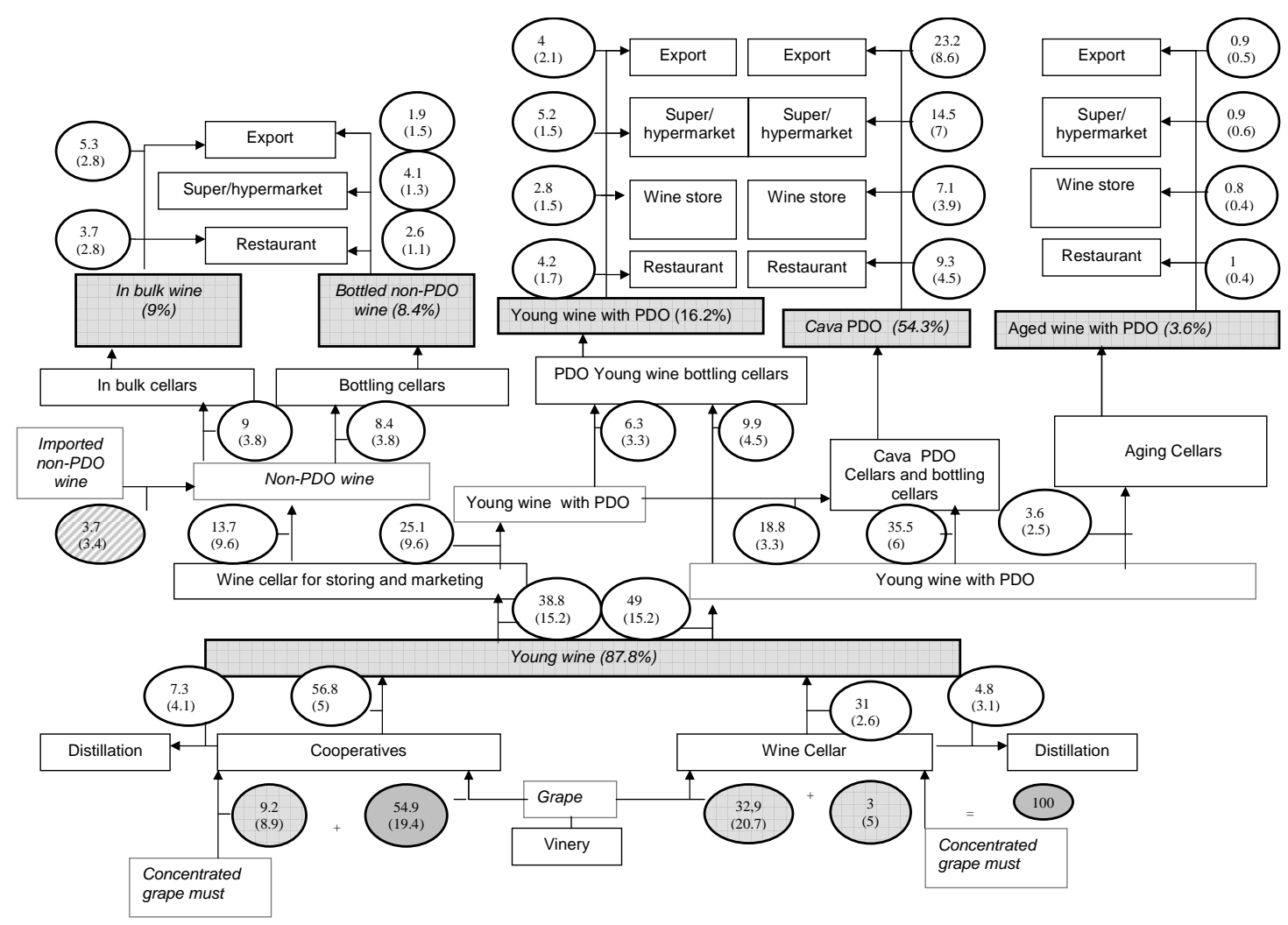

Source: own source.

Note: Values are expressed in \% and are at the data means. Standard deviations are in parenthesis 


\section{Notes}

[1] These designations are Alella, Catalunya (recently created), Conca de Barberà, Costers del Segre, Empordà-Costa Brava, Montsant, Penedès, Pla del Bages, Priorat, Tarragona and Terra Alta. Cava (sparkling wine) is another important PDO in Catalonia. Although it is not circumscribed to this autonomous community, $95 \%$ of its production is located there.

[2] Other upublished papers using the Delphi technique to analize the Spanish agricultural sector are Salazar and Sayadi (2006) and Soliño (2003).

${ }^{[3]}$ More detail on expert responses is available from the authors upon request. 